\title{
Effect of adding bulking materials over the composting process of municipal solid
} biowastes

\author{
Ricardo Oviedo-Ocaña ${ }^{1,2}$, Luis Fernando Marmolejo-Rebellón', Patricia Torres-Lozada1, \\ Martha Daza ${ }^{1}$, Mercedes Andrade ${ }^{1}$, Wilmar Alexander Torres-López ${ }^{1}$, and Rodrigo Abonia-Gonzalez ${ }^{3 *}$
}

Biowastes $(\mathrm{BW})$, the main raw materials for the composting installations in developing countries, are characterized for containing uncooked food wastes $(\mathrm{FW})$, high moisture content, low porosity, acidic $\mathrm{pH}$, and low $\mathrm{C} / \mathrm{N}$ ratios which affects the overall composting process (CP). In this study, we evaluated the effect of adding sugarcane bagasse (SCB) and star grass (SG) (Cynodon plectostachyus (K. Schum.) Pilg.) as bulking materials (BM) over the quality of the substrate, progress of the process, and quality of the obtained product. In this sense, two pilot-scale experiments were performed. The first one contained a substrate formed by $78 \% \mathrm{BW}$ and $22 \% \mathrm{SCB}$ (pile A). The second experiment contained a substrate formed by $66 \% \mathrm{BW}$ and $34 \%$ SG (pile B). For each experiment, control treatments (piles $\mathrm{A}^{\prime}$ and $\mathrm{B}^{\prime}$ respectively) were performed by using $100 \% \mathrm{BW}$ without BM. The results showed that in both cases the adding of BM improved substrate quality $(\mathrm{pH}$, moisture, and total organic $\mathrm{C}$ content [TOC]), speeding up the starting step (2-3 d) and reducing the duration of the thermophilic phase of $\mathrm{CP}(3 \mathrm{~d})$. However, the physico-chemical properties of both BM increased cooling and maturation phases duration (between 15 and 20 d). Obtained products quality was improved in terms of higher TOC, cation-exchange capacity, bulk density, and higher water holding capacity. Application of obtained products A and B could improve some soil properties like major nutrient, water retention, and increasing the organic matter.

Key words: Biowastes, bulking materials, composting processes, municipal solid wastes, star grass, sugarcane bagasse.

\section{INTRODUCTION}

Biowastes (BW) are the major fraction of municipal solid wastes (MSW) in developing countries being food wastes (FW) like fruits and vegetables their main components (Gustavsson et al., 2011). Composting process (CP) is one of the best-known methods used for BW biological stabilization. For this process, organic components of substrate are transformed in stable materials which could further be used both as organic material source and as organic fertilizers for agricultural applications and soil amendment processes (Haug, 1993; Chiumenti et al., 2005).

The $\mathrm{CP}$ effectivity and quality of obtained product depends on initial characteristics of material to be processed (substrates) (viz., its biodegradability and nutrient availability) but also of the control of several key

${ }^{1}$ Universidad del Valle, Facultad de Ingeniería, A.A. 25360, Cali, Colombia.

${ }^{2}$ Universidad Industrial de Santander, Facultad de Ingenierías Fisicomecánicas, Carrera 27 Calle 9, Bucaramanga, Colombia.

${ }^{3}$ Universidad del Valle, Facultad de Ciencias Naturales y Exactas, A.A. 25360, Cali, Colombia.

*Corresponding author (rodrigo.abonia@correounivalle.edu.co).

Received: 12 November 2014.

Accepted: 16 July 2015.

doi:10.4067/S0718-58392015000500013 factors such as temperature, aeration, $\mathrm{pH}$, and moisture (Zhu, 2007; De Guardia et al., 2010). According to Agnew and Leonard (2003) and Chiumenti et al. (2005), $\mathrm{CP}$ might be efficiently developed employing substrates with $\mathrm{C} / \mathrm{N}$ ratios in range of $25-30$, moisture content between $50 \%-60 \%$, and $\mathrm{pH}$ values of 6.5-7.5. However, $\mathrm{BW}$ are generally characterized by $\mathrm{C} / \mathrm{N}$ values lower than 20, moisture higher than $70 \%$, and acidic $\mathrm{pH}$, affecting negatively processing time, transformation efficiency rates and quality of the obtained product (Adhikari et al., 2008; Kumar et al., 2010; Sundberg et al., 2011). Additionally, they could generate environmental secondary contaminant products such as leachates, ammonia, and greenhouse gases (Yang et al., 2013).

Diverse strategies to control moisture and $\mathrm{pH}$ dropping have been proposed. Among them, adding bulking material $(\mathrm{BM})$ or increasing aeration rate have widely been used (Sundberg and Jönsson, 2005; Epstein, 2011). Regarding to BM they have been used to modify physical properties of substrates, improving biological activity conditions and biodegradation kinetic (source of $\mathrm{C}$, particle size, volumetric density [VD], porosity, and regulation of moisture) (Haug, 1993; Yang et al., 2013; Li et al., 2013).

Several experiences in which different BM has been applied in order to optimize $\mathrm{CP}$ of $\mathrm{BW}$ or $\mathrm{FW}$ have been documented. For example, wheat residue pellets 
and chopped hay were used by Adhikari et al. (2008), green wastes and cardboard paper by Francou et al. (2008), raked leaves and grass clippings by Kumar et al. (2010). Likewise, Li et al. (2013) reported use of sawdust followed by sugarcane bagasse (SCB), rice husk, and wood shavings. Selection of appropriate BM should be accompanied by not only its physico-chemical characteristics but also its availability and costs related with its raw source.

Regarding to the use of grass residues as BM, they have been identified as additional energy and nutrients (like N) sources, regulates moisture excess proceeding from FW and improve structure and aeration of substrates (López et al., 2010). Other authors (Francou et al., 2008; Kumar et al., 2010) have used this material mixed with FW improving the $\mathrm{CP}$ and obtained product quality. From a previous study, Oviedo-Ocaña et al. (2013) demonstrated that adding $17 \%$ of star grass (SG, Cynodon plectostachyus [K. Schum.] Pilg.) in a $\mathrm{CP}$ of BW improved substrate characteristics, degradation rate, hygienization conditions and quality of obtained product. In turn, $\mathrm{SCB}$ is a lignocellulosic material composed mainly by $50 \%$ cellulose, $25 \%$ hemicellulose, and $25 \%$ lignin (Balakrishnan and Batra, 2011), which have also been used in different studies as BM (Iqbal et al., 2010). In this sense, it have been reported some CP using SCB mixed with bovine manure and vegetables (Monson and Murugappan, 2010) or with press mud obtained from sugarcane industry (Meunchang et al., 2005).

According to above, there is still a necessity of improving $\mathrm{CP}$ and obtained products quality from $\mathrm{BW}$ produced in developing countries, as well as, conduct researches aimed to increasing the competitiveness of this option for MSW management. In this sense and continuing with our current program on the identification and evaluation of raw wastes as potential supporting materials (Oviedo-Ocaña et al., 2013), in this study was evaluated the effect of adding SG and SCB as BM in $\mathrm{CP}$ of $\mathrm{BW}$ obtained from municipal solid wastes over physico-chemical properties of $\mathrm{BW}$ and behavior of some variables like temperature, $\mathrm{pH}$, and volatile solids. Furthermore, physico-chemical and microbiological qualities of obtained products were also considered.

\section{MATERIALS AND METHODS}

\section{Description of the experiments}

This study was carried out at pilot-scale in a locality of the Valle del Cauca Department, Colombia, accounting with a MSW plant were the source separation and the selective collection of the MSW have effectively been implemented. The SCB was supplied by a sugarcane micro-enterprise located in the municipality and SG from grass clipping of surrounding green areas of the locality. The study consisted of two experimental composting installations of $\mathrm{BW}$, in the first one (experiment 1, piles A) it was evaluated the effect of adding SCB to the BW over the $\mathrm{CP}$ and the quality of the obtained product, and the second one (experiment 2, piles B) evaluated the effect of adding $\mathrm{SG}$ to the $\mathrm{BW}$ over the same parameters.

The characteristics of each pile were: Pile A was composed by $78 \% \mathrm{BW}$ and $22 \%$ SCB. This composition was proposed after mass balances supported by physicochemical characterization of SCB to be used as well as the BW of the locality in order to obtain a final $\mathrm{C} / \mathrm{N}$ ratio of 25-30 (Haug, 1993). The information employed for calculations was: (i) SCB: total organic $\mathrm{C}$ (TOC) = $42.61 \%$; total $\mathrm{N}$ by Kjeldahl $\left(\mathrm{N}_{\text {Total }}\right)=0.37 \%$; moisture $=$ $32.5 \% ; \mathrm{C} / \mathrm{N}$ ratio $=115.0$, and (ii) $\mathrm{BW}: \mathrm{TOC}=29.76 \%$; $\mathrm{N}_{\text {Total }}=1.46 \% ;$ moisture $=76.0 \% ; \mathrm{C} / \mathrm{N}$ ratio $=20.79$. Pile $\mathrm{B}$, composed by $66 \% \mathrm{BW}$ and $34 \% \mathrm{SG}$. This composition was established after previous results obtained by OviedoOcaña et al. (2013). The compositions of both types of piles are in wet-weight basis; additionally, for each experiment control assays were performed consisting in $100 \%$ BW (they will be referred to as Pile $\mathrm{A}^{\prime}$ and $\mathrm{B}^{\prime}$, respectively).

\section{Substrate characterization}

The BW were generated by the total homes of the municipality, they were source-separated, selectively collected and were stored at homes during $4 \mathrm{~d}$. Before the experiments started, non-biodegradable residues were manually removed from BW. The SCB had 2 wk storage within a covered space while the SG was clipped a previous day before the experiment started and was stored until its use. All substrates (A, B, A', B', SCB, and SG) were manually triturated until reaching recommended particle size for the process $(5-7 \mathrm{~cm}$ ) (Agnew and Leonard, 2003). Before the piles were installed, all components were carefully mixed as homogeneous as was possible using the calculated ratios for each component.

Representative samples, $2 \mathrm{~kg}$ each one, of the above substrates were processed by following sampling quartering method described by Sakurai (2001) and sample preservation techniques (Sullivan and Miller, 2001). These samples were subjected to measurement of $\mathrm{pH}$, moisture, ashes, total $\mathrm{K}$, total $\mathrm{P}$, and TOC variables by methods described in the Colombian Technical Norm (NTC) 5167 (Icontec, 2003). The $\mathrm{N}_{\text {Total }}$ was determined by technical norm NTC 370 (Icontec, 1997). Each analysis was carried out by duplicate and when any coefficient of variation was larger than $10 \%$, the measurement was repeated again.

\section{Experimental assembly and monitoring process}

Once the materials were mixed, installation of the piles was performed by triplicate for each substrate (piles $\mathrm{A}^{\prime}$ $\times 3, \mathrm{~A} \times 3, \mathrm{~B}^{\prime} \times 3$, and $\mathrm{B} \times 3$ ). The piles had $318 \mathrm{~kg}$ for experiment 1 and $258 \mathrm{~kg}$ for experiment 2 . All piles were conic shaped, 0.6-0.8 $\mathrm{m}$ height, and were subjected to the same environmental conditions in a location protected 
with impermeable roof, flat floor, and $2 \mathrm{~m}$ of minimal distance between them. Both experiments were carried out through a completely random design to determine possible differences between products obtained from each treatment.

The recommendations made by Adhikari et al. (2008) and Kumar et al. (2010), parameters like temperature, $\mathrm{pH}$, moisture, volatile solids (VS), electrical conductivity (EC), and germination indices (GI) were chosen as control variables. Temperature was daily measured at the centroid of each pile by using a $30 \mathrm{~cm}\left(0-100{ }^{\circ} \mathrm{C}\right)$ thermometer (Compost thermometer, Reotemp, San Diego, California, USA). For $\mathrm{pH}$ and moisture measurements, it was taken $200 \mathrm{~g}$ sample from each pile, proceeding from four opposite points and mixed together (Sullivan and Miller, 2001). The $\mathrm{pH}$ was potentiometrically measured to an aqueous extract obtained from a stirred mixture of the sample and distilled water $(1: 5 \mathrm{w} / \mathrm{w})$ by using a pHmeter (WTW Model 315i, Wissenschaftlich-Technische Werkstätten GmbH, Weilheim, Germany). To measure water content, a moisture analyzer (Ohaus MB-35 Ohaus Corporation, Pine Brook, New Jersey, USA) was used. All measurements were performed daily during the first $4 \mathrm{wk}$, and then two times per week until the experiment was completed.

As recommended by Agnew and Leonard (2003), the moisture was kept up to $40 \%$ by moisturizing with water. The moisture and pile-weight values were used to determine water volume to be added. A uniform distribution of water was endeavored during the moisturizing process. A turning process was used when the piles reached temperatures of $65^{\circ} \mathrm{C}$ or higher and to avoid compacting of the material. The fact that advisable changes in control variables are indicators that $\mathrm{CP}$ is in progress and such changes could affect significantly the quality of the obtained products (Li et al., 2013), a continuous monitoring of process was performed until piles reached temperatures nearby to the ambient $\left( \pm 5^{\circ} \mathrm{C}\right)$ and until the products acquired smell of soil. Both criteria indicated the end of maturation phase. Additionally, in maturation phase, self-heating tests were performed in order to verify if increasing of temperature would not occur during the process.

Quantification of VS was performed by calcination techniques at $550{ }^{\circ} \mathrm{C}$ by following recommendations of Ali et al. (2013). Thus, a representative sample of the material, removed from the process, was used to determine its weight at $105{ }^{\circ} \mathrm{C}$ during $24 \mathrm{~h}$ and at $550{ }^{\circ} \mathrm{C}$ during $4 \mathrm{~h}$. The EC was measured through a potentiometric method by using a conductivimeter (model 325, WTW Wissenschaftlich-Technische Werkstätten GmbH, Weilheim, Germany). The GI was measured by determining the sensibility of the radish (Raphanus sativus L.) toward the obtained products and following the procedures established by Varnero et al. (2007). Assays to determine VS, EC, and GI, were performed by triplicate and mean values of each measurement for each pile were reported. The obtained information was used to make a descriptive analysis by relating control variables evolution, namely, temperature, $\mathrm{pH}, \mathrm{VS}, \mathrm{GI}$, and EC with respect to starting substrates quality.

\section{Product quality and statistical analyses}

Once the process finished, representative samples for each pile were taken by following the procedure established by Sullivan and Miller (2001). Variables like $\mathrm{K}\left(\mathrm{K}_{2} \mathrm{O}\right)$ (performed by capillary electrophoresis, Standard Methods-SM 3112A), ashes, cation-exchange capacity (CEC), TOC, water holding capacity (WHC), BD, and moisture (according to the norm NTC 5167), EC, and $\mathrm{pH}$ (by potentiometric techniques) according to norm NTC 5167 (Icontec, 2003), $\mathrm{N}_{\text {Total }}$ (by Kjeldahl method) according to the norm NTC 370 (Icontec, 1997), and total $\mathrm{P}\left(\mathrm{P}_{2} \mathrm{O}_{5}\right)\left(\mathrm{P}_{\text {total }}\right)$ (by spectrophotometry) according to the norm NTC 243 (Icontec, 2001) were measured by duplicate. Microbiologic assays (total coliforms [TC] and total fecal coliforms [TFC]) were performed according to the norm of United States Environmental Protection Agency (US-EPA, 1994). Quality parameters of obtained products were compared with the limit parameters established by the Colombian Norm for the Quality of the Composts - NTC 5167 (Icontec, 2003). In all cases, aleatorization tests were applied to determine if significant differences occurred (5\% significance level) between quality parameters of the obtained products (piles A and B) against their corresponding controls $\mathrm{A}^{\prime}$ and $\mathrm{B}^{\prime}$. The data processing statistics were performed by using freely available programming software for data analysis and graphics R version 2.12.1 (R Development Core Team, 2008).

\section{RESULTS AND DISCUSSION}

\section{Substrate characterization}

Table 1 summarizes the initial physico-chemical characteristics of substrates (A, B), controls ( $\left.\mathrm{A}^{\prime}, \mathrm{B}^{\prime}\right)$, as well as BM (SCB and SG) studied. The BW of the locality in study presented high content of uncooked FW (OviedoOcaña et al., 2013). According to literature (Kumar et al., 2010; Li et al., 2013), this type of FW possess special physico-chemical properties such as, organic substances easy-to-degrade, high $\mathrm{N}_{\text {total }}$ content, and low $\mathrm{C} / \mathrm{N}$ ratio. In consequence, similar data were obtained for our BW.

Starting BW's (controls $\mathrm{A}^{\prime}$ and $\mathrm{B}^{\prime}$ ) presented acidic $\mathrm{pH}$ in the range of 5.67 and 5.39, respectively, which could be associated with low molecular weight fatty acid generated, formed as anaerobic intermediates, during storing period of the BW at homes (Krogmann et al., 2010). This process could increase not only temperature up to thermophilic range (Sundberg et al., 2004) but also mesophilic phase duration (Li et al., 2013). Additionally, starting controls $\mathrm{A}^{\prime}$ and $\mathrm{B}^{\prime}$ showed high moisture content $(70.8 \%$ and 
Table 1. Physicochemical characterization of the substrates in experiments 1 and 2.

\begin{tabular}{|c|c|c|c|c|c|c|}
\hline \multirow[b]{2}{*}{ Parameters } & \multicolumn{3}{|c|}{ Experiment 1} & \multicolumn{3}{|c|}{ Experiment 2} \\
\hline & Pile A' (control) & SBC & Pile A & Pile B' (control) & SG & Pile B \\
\hline $\mathrm{pH}$ & 5.67 & 5.12 & 5.57 & 5.39 & 8.30 & 6.12 \\
\hline Moisture, \% & $70.8 \pm 5.88$ & $41.0 \pm 0.66$ & $65.7 \pm 1.90$ & $78.99 \pm 0.82$ & $74.19 \pm 0.32$ & $72.46 \pm 1.63$ \\
\hline TOC, $\%$ & $27.26 \pm 1.50$ & $43.56 \pm 0.83$ & $37.32 \pm 2.00$ & $25.94 \pm 0.02$ & $40.72 \pm 1.17$ & $25.85 \pm 0.93$ \\
\hline $\mathrm{N}_{\text {Total }}, \%$ & $1.27 \pm 0.00$ & $0.47 \pm 0.00$ & $1.17 \pm 0.02$ & $1.08 \pm 0.02$ & $1.53 \pm 0.04$ & $1.48 \pm 0.02$ \\
\hline $\mathrm{C} / \mathrm{N}$ & 21.5 & 91.8 & 32.0 & 24.0 & 26.6 & 17.5 \\
\hline Ashes, $\%$ & $34.38 \pm 1.03$ & $7.07 \pm 0.24$ & $21.87 \pm 0.09$ & $31.00 \pm 0.90$ & $13.26 \pm 0.20$ & $35.54 \pm 0.14$ \\
\hline $\mathrm{K}_{\text {Total }}, \%$ & $1.06 \pm 0.01$ & $0.11 \pm 0.01$ & $1.33 \pm 0.02$ & $1.75 \pm 0.03$ & $1.60 \pm 0.05$ & $2.05 \pm 0.10$ \\
\hline $\mathrm{P}_{\text {Total }}, \%$ & $0.64 \pm 0.05$ & $0.64 \pm 0.05$ & $1.06 \pm 0.09$ & $0.21 \pm 0.01$ & $0.18 \pm 0.00$ & $0.59 \pm 0.01$ \\
\hline
\end{tabular}

Average data \pm standard deviation.

SBC: Sugarcane bagasse; SG: star grass; TOC: total organic $\mathrm{C}$; $\mathrm{N}_{\text {Total }}$ : total $\mathrm{N}$; $\mathrm{K}_{\text {Total }}$ : total $\mathrm{K}$, $\mathrm{P}_{\text {Total }}$ : total P.

$79.0 \%$ respectively) associated with FW (Adhikari et al., 2008; Li et al., 2013), which generally affect the porosity of the material, the oxygen diffusion and progress of the whole process (Krogmann et al., 2010).

Regarding to the TOC, controls $\mathrm{A}^{\prime}$ and $\mathrm{B}^{\prime}$ showed values comparable with those reported in other contexts (30.5\% by Forster-Carneiro et al., 2008 and $37.8 \%$ by Tosun et al., 2008). The $\mathrm{N}_{\text {Total }}$ parameter had different values for each experiment, which could be associated with previous transformations during the handling and storing of residues before the piles were assembled. Controls $\mathrm{A}^{\prime}$ and $\mathrm{B}^{\prime}$ were characterized by an important content of $\mathrm{K}_{\text {total }}(1.06 \%$ and $1.75 \%$, respectively), which should be associated with the high presence of plantain peels in them. On the other hand, $\mathrm{P}_{\text {Total }}$ content was limited $(0.64 \%$ and $0.21 \%$, respectively), associated with presence of vegetables and legumes as well as a low content of ashes $(34.38 \%$ and $31.00 \%$, respectively) were attributed to their low content of impurities.

The adding of SCB to the BW (substrate A) had a positive effect over the initiation step of process due to: (i) Moisture was reduced from $70.8 \%$ (control $\mathrm{A}^{\prime}$ ) to $65.7 \%$, which falls within the recommended range for the initiation step of this type of processes $(60 \%-70 \%)$ (Chiumenti et al., 2005); (ii) TOC value increased from $27.26 \%$ (Control $\mathrm{A}^{\prime}$ ) up to $37.32 \%$ as consequence of the high content of $\mathrm{C}$ present in this material $(43.56 \%$ ) (Iqbal et al., 2010), as well as (iii) the increasing of $\mathrm{C} / \mathrm{N}$ ratio from 21.5 (control $\mathrm{A}^{\prime}$ ) up to 32.0 , which also is nearly to that recommended for the initiation step of this type of processes (25-30) (Agnew and Leonard, 2003). On the other hand, the SCB did not affect the overall $\mathrm{pH}$ of substrate A (5.57), due to similar values between control $\mathrm{A}^{\prime}$ and the SCB (5.67 vs. 5.12, respectively). However its addition effectively generated a dilution of the $\mathrm{N}_{\text {Total }}$ by comparing the control $\mathrm{A}^{\prime}$ (1.27) with the substrate A (1.17), due to the low content of this element in SCB (0.47), which coincide with data reported elsewhere $(0.35 \%$ to $0.45 \%)$ (Meunchang et al., 2005; Satisha and Devarajan, 2007).

Similarly, adding of SG to the BW (substrate B) had also a positive effect over the $\mathrm{pH}$ (it was increased from 5.39 for control $\mathrm{B}^{\prime}$ to 6.12 for substrate B) in agreement with previous reports which recommend the adding of BM's to improve the starting $\mathrm{pH}$ and hence the $\mathrm{CP}$ at all (Smårs et al., 2002). Although SG showed a similar moisture value as substrate B $(74.19 \%$ and $72.46 \%$, respectively), its presence in substrate B should have increased porosity and aeration of this material, due to its fibrous characteristics (Dormond et al., 1998). In spite that SG had a high TOC value (40.72\%) it did not improve TOC value for substrate B $(25.85 \%)$ respect to its control $\mathrm{B}^{\prime}(25.94 \%)$. This finding is in agreement with previous reports Oviedo-Ocaña et al. (2013). Regarding to the $\mathrm{N}$ content, the $\mathrm{SG}$ reduced the $\mathrm{C} / \mathrm{N}$ ratio in substrate $\mathrm{B}$ (17.47) respect to its control $\mathrm{B}^{\prime}$ (24.02), but such value is comparable with (19.6) obtained by Kumar et al. (2010), from a substrate formed by a mixture of FW and raked leaves and grass clippings, which resulted completely useful for CP.

\section{Temperature analysis}

Figures 1 and 2 represent temperature evolution of piles for the experiments 1 and 2, respectively. In general, this parameter showed similar values in piles for each substrate (A', A, B', and B). Except for piles A, in the remaining cases it was observed a typical temperature evolution for a $\mathrm{CP}$, with sequential phases (mesophilic $<45{ }^{\circ} \mathrm{C}$, thermophilic $>45{ }^{\circ} \mathrm{C}$, cooling $<45{ }^{\circ} \mathrm{C}$, and maturation room temperature) (Chiumenti et al., 2005). It was observed that for the control piles ( $\mathrm{A}^{\prime}$ and $\mathrm{B}^{\prime}$ ) the thermophilic temperatures were reached about $2 \mathrm{~d}$ after they were prepared, however, in cases were BM were used (substrates A and B), this temperature took just $1 \mathrm{~d}$. This finding demonstrates a positive effect of adding $\mathrm{BM}$ for the $\mathrm{CP}$ of this kind of $\mathrm{BW}$ in agreement with previous reports (Francou et al., 2008; Kumar et al., 2010). Lowering of the overall time is a direct consequence of the BM facilitating the operation and monitoring of the $\mathrm{CP}$.

The relative fast increasing of temperature up to thermophilic values in all substrates ( $\mathrm{A}^{\prime}, \mathrm{A}, \mathrm{B}^{\prime}$, and $\mathrm{B}$ ) could be related with transformation of easy-to-degrade fractions proceeding from FW like carbohydrates, proteins and amino acids present in the them (Krogmann et al., 2010). Lower required time to reach thermophilic 
temperature in piles using BM (A and B) should be associated with better processing conditions like nearly neutral pH (with SG) and major porosity of the material,
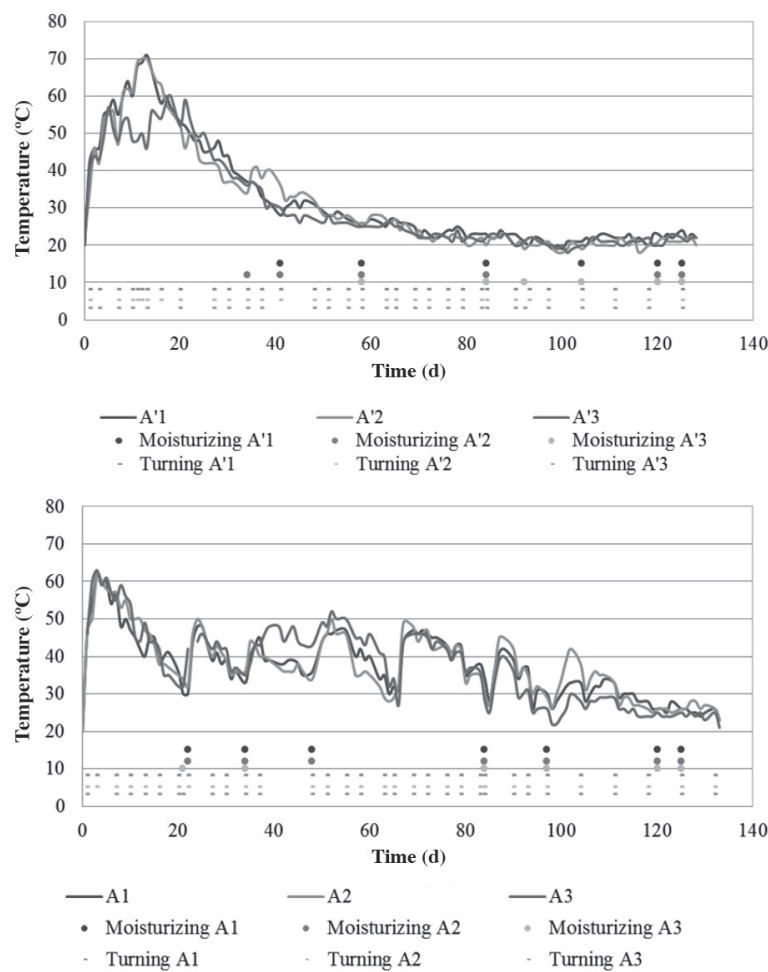

Figure 1. Temperature evolution in piles of the experiment 1.
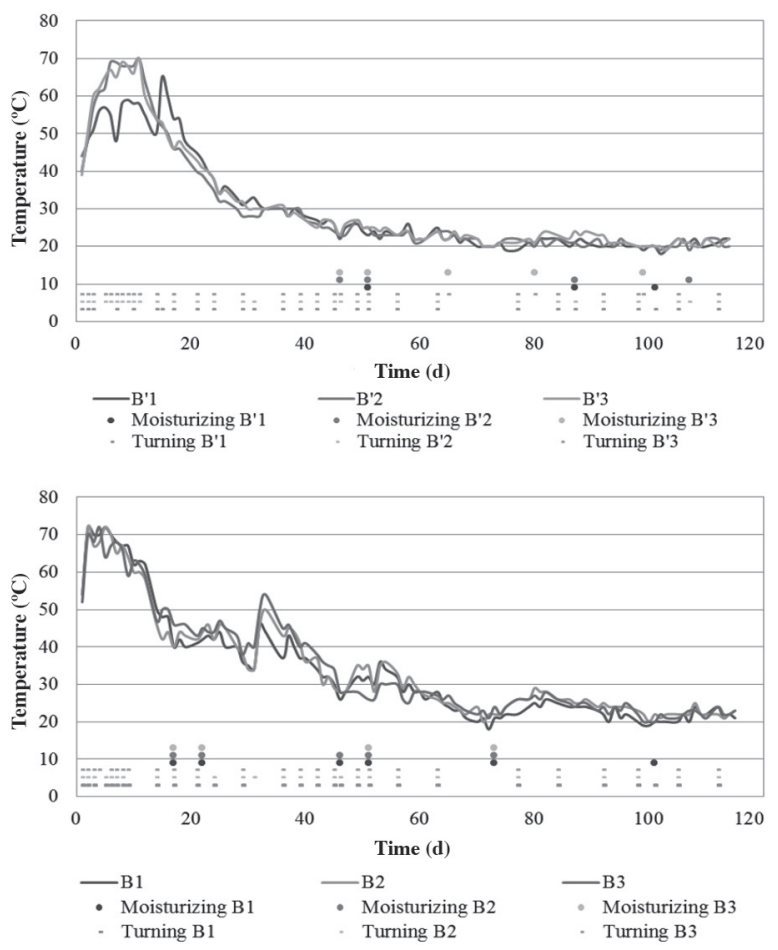

Figure 2. Temperature evolution in piles of the experiment 2. both improving environment for microbial metabolism (Gajalakshmi and Abbasi, 2008).

In general, piles with BM (A and B) reached faster their maximum temperatures (2-3 d) and had minor lasting of thermophilic phase (9-19 d) than their control piles ( $A^{\prime}$ and $\mathrm{B}^{\prime}$ ) (11-18 $\mathrm{d}$ for maximum temperature and 19-25 $\mathrm{d}$ for lasting) (Figures 1 and 2). Nevertheless the above differences, in all piles ( $\mathrm{A}^{\prime}, \mathrm{B}^{\prime}, \mathrm{A}$, and $\mathrm{B}$ ) hygienization conditions were reached satisfactorily with thermophilic temperature duration up to $4 \mathrm{~d}$, according to Haug (1993).

As is observed in Figures 1 and 2, control piles ( $A^{\prime}$ and $\mathrm{B}^{\prime}$ ) as well as piles $\mathrm{B}$ shows very similar temperature decaying graphics with pronounced decaying during days 20 to 50 for ( $\mathrm{A}^{\prime}$ and $\mathrm{B}^{\prime}$ ) and days 15 to 65 for $\mathrm{B}$, followed by extended decaying until their ending, in agreement with (Chiumenti et al., 2005; Gajalakshmi and Abbasi, 2008). In contrast, piles A did not follow a similar evolution presenting continuous temperature oscillations. This fact could be associated with presence of hard-to-degrade compounds in SCB, which slowed and then speeded up the process in an alternate form each time the process was submitted to operation (i.e. turning and moisturizing). After the experiments finished, control piles $\left(\mathrm{A}^{\prime}\right.$ and $\mathrm{B}^{\prime}$ ) reached almost the ambient temperature while piles (A and $\mathrm{B}$ ) reached 2 or $3^{\circ} \mathrm{C}$ higher.

\section{pH Determination}

Figures 3 and 4 show the evolution of the $\mathrm{pH}$ both in piles of the experiment 1 (piles A) and experiment 2 (piles B), respectively. Excepting for piles B, all substrates had initial acidic $\mathrm{pH}$ values, which could inhibit microorganisms growing as well as determine the relative reactions of some substrate components ( $\mathrm{Li}$ et al., 2013). However, it was observed that this property was not limiting for processes progress because the easy-to-degrade fractions were fairly
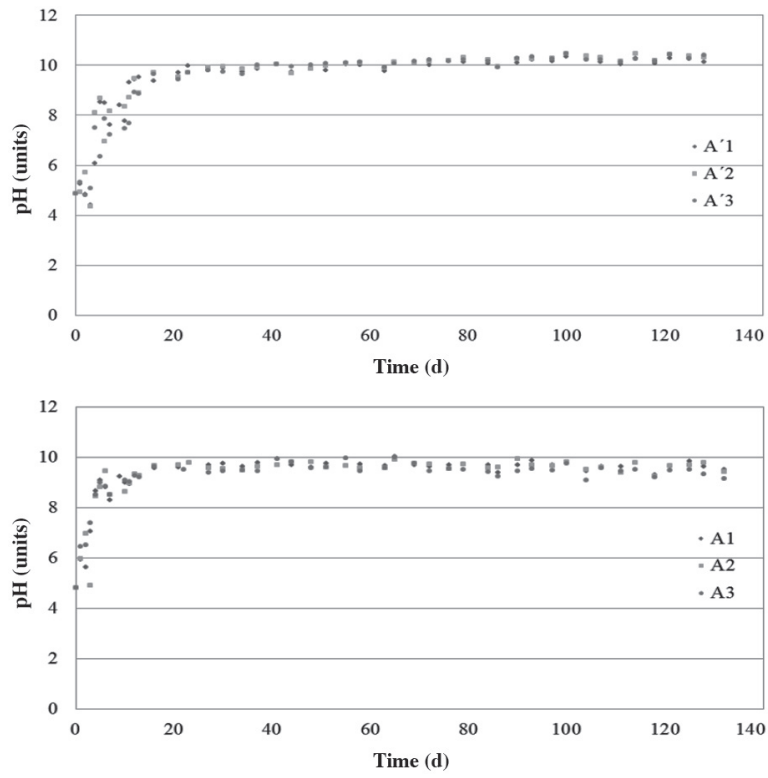

Figure 3. pH evolution in piles of the experiment 1. 

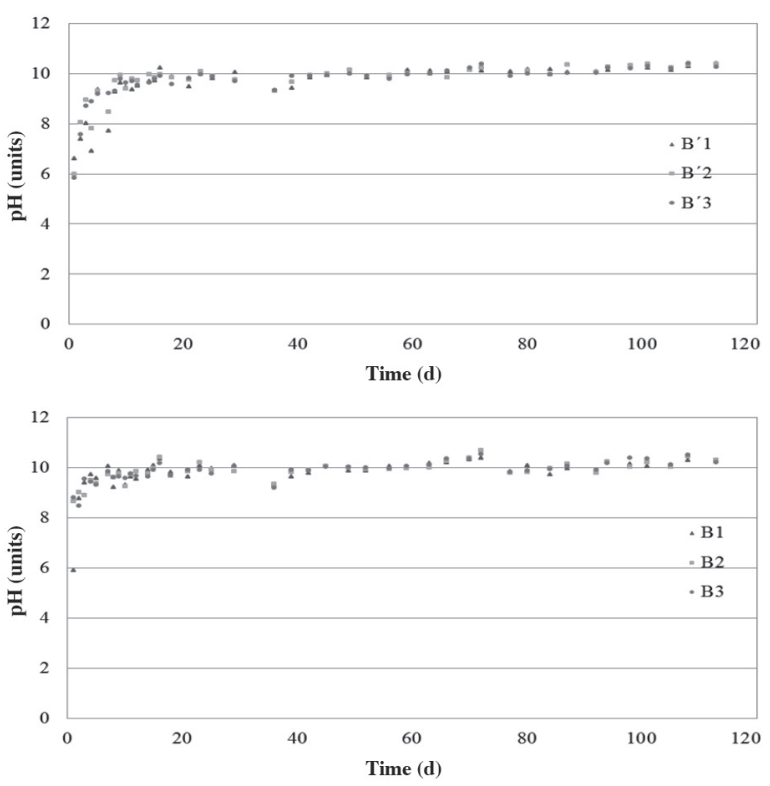

Figure 4. pH evolution in piles of the experiment 2.

transformed under controlled conditions (i.e. controlling the aeration and compacting of the materials). Higher value of $\mathrm{pH}$ was observed in piles $\mathrm{B}$ and it is associated with SG presence, characterized by high basic content $(\mathrm{pH}$ $=8.3$ ), which should contribute to reduce the formation of organic acids, typical by-products proceeding from the microbial decomposition of the organic materials (Smårs et al., 2002).

After $1^{\text {st }}$ day (for piles B) and $4^{\text {th }}$ day (for piles A, $\mathrm{A}^{\prime}$, and $\mathrm{B}^{\prime}$ ) alkaline values of $\mathrm{pH}$ were observed, which could be associated with the fact that organic acids formed normally are easily biodegraded and consumed by the microorganisms with the subsequent increasing of the $\mathrm{pH}$ (Sundberg and Jönsson, 2005). In the same way, the releasing of $\mathrm{CO}_{2}$ during the aeration process of the experimental unities should not have allowed its accumulation into piles, avoiding subsequent formation of carbonic acid and derivatives (by action of the water and bacteria); in contrary case low $\mathrm{pH}$ would be observed (Haug, 1993).

After the processes finished, piles A', B', and B showed alkaline $\mathrm{pH}$ values in the range of 8-10. This finding could be associated with high $\left(\mathrm{K}^{+}\right)$content in such substrates. This metal, in its water-soluble form, combined with $\left(\mathrm{HCO}_{3}{ }^{\circ}\right)$ ion generated during the organic material mineralization step could form a strong base like $\mathrm{KOH}$ responsible of alkaline $\mathrm{pH}$ observed (Kalemelawa et al., 2012). In the case of piles $\mathrm{A}$, lower $\mathrm{pH}$ values observed could be associated with initial acidic pH of the SCB.

\section{Volatile solids}

Figure 5 represents evolution of VS both in experiment 1 (piles $\mathrm{A}^{\prime}$ and $\mathrm{A}$ ) and experiment 2 (piles $\mathrm{B}^{\prime}$ and $\mathrm{B}$ ). Piles containing BM (A and B) showed higher content of VS, which should be associated with their higher TOC
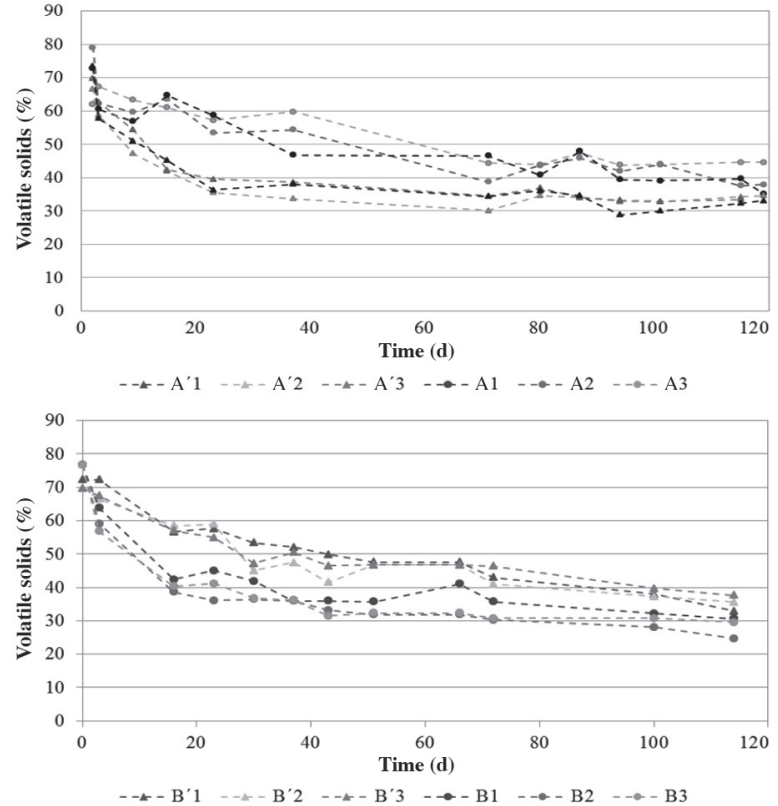

Experiment 1: $78 \%$ Biowastes (BW) and 22\% sugarcane bagasse; Experiment 2: $66 \% \mathrm{BW}$ and 34\% star grass.

Figure 5. Volatile solids (VS) evolution in piles of the experiments 1 and 2.

values (Table 1). Pronounced decaying of VS during the first $20 \mathrm{~d}$ (i.e. mesophilic and thermophilic phases) in all piles ( $\mathrm{A}^{\prime}, \mathrm{B}^{\prime}, \mathrm{A}$, and $\mathrm{B}$ ) (Figure 5), could be associated to the fact that the easy-to-degrade organic materials are transformed by the microorganisms during the mesophilic and thermophilic phases of the process, releasing $\mathrm{CO}_{2}$ generated by the microbial breathing (Haug, 1993).

Relative lower decaying slope observed for piles A respect to their control $A^{\prime}$ during the first two phases of the process is associated with presence of hard-to-degrade materials like lignin (proceeding form the SCB), which protect the fibrous cells (cellulose and hemicellulose) of microbial attack (Haug, 1993), interestingly, the same evolution was not observed when comparing piles B' with B (using SC as BM).

After the day 20 (cooling and maturation phases), it was observed a less pronounced slope of decaying of VS in all piles ( $\mathrm{A}^{\prime}, \mathrm{B}^{\prime}, \mathrm{A}$, and $\left.\mathrm{B}\right)$, which could be associated with the decomposition of the medium- and hard-to-degrade materials present in the all substrates, as previously have been observed in other studies (Zhu, 2007). Regarding to the decreasing of the VS in experiments 1 and 2, it was observed that piles $\mathrm{A}^{\prime}, \mathrm{A}, \mathrm{B}^{\prime}$, and $\mathrm{B}$ showed decreasing percentages of VS of $56.68 \% \pm 1.81 \%, 47.18 \% \pm 10.88 \%, 63.04 \% \pm 4.07 \%$ and $49.81 \% \pm 4.26 \%$, respectively, by comparing the starting VS values with the final ones at the end of their processes. These relatively high decreasing percentages of VS reflect a significant progress in organic materials transformation in all experiments; although, the major decreasing percentages of VS were observed when the BM were not present (in control piles $\mathrm{A}^{\prime}$ and $\mathrm{B}^{\prime}$ ) (Figure 5). 


\section{Products quality}

Table 2 shows results related to obtained products quality from each type of pile for each experiment. When comparing control piles $\mathrm{A}^{\prime}$ with its product $\mathrm{A}$ in experiment 1 , it is observed that just 4 of 14 evaluated parameters $\left(\mathrm{N}_{\text {Total }}, \mathrm{C} / \mathrm{N}\right.$ ratio, $\mathrm{TC}$, and $\left.\mathrm{TFC}\right)$ did not show significant differences between them ( $\mathrm{p}$-value $>0.05$ ). The remaining 10 parameters were significantly different (p-value <0.05) (Table 2). Regarding to experiment 2, by comparing control piles $\mathrm{B}^{\prime}$ with products $\mathrm{B}$, significant differences were observed in 6 of 14 parameters (TOC, $\mathrm{N}_{\text {Total }}$, ashes, $\mathrm{P}_{\text {Total }}, \mathrm{BD}$, and $\mathrm{WHC}$ ). According to the above results, the adding of both $\mathrm{BM}$ (SCB and $\mathrm{SG}$ ) effectively affected composition of starting BW (controls $A^{\prime}$ and $B^{\prime}$ ) having the SCB a higher effect than SG.

Both products ( $\mathrm{A}^{\prime}$ and $\mathrm{A}$ ) of the experiment 1 , showed $\mathrm{pH}$ values that agrees with the NTC 5167 norm (Icontec, 2003), being the $\mathrm{pH}$ of products A the closest to neutrality (7.38). Contrary, for experiment 2 , both products ( $\mathrm{B}^{\prime}$ and B) had $\mathrm{pH}$ values higher (10.1 and 9.9, respectively) than the limit (9.0), which could restrict continuous applications of these products to alkaline soils (Pigozzo et al., 2006).

Regarding to the moisture, in both experiments the piles using BM required higher moisturizing to keep necessary moisture level for biological activity, than their control piles. Indeed, piles A employed an excess of $24 \%$ of water as well as piles $\mathrm{B}$ required a $32 \%$ of excess, comparing with their controls $\mathrm{A}^{\prime}$ and $\mathrm{B}^{\prime}$, respectively. Particularly, products of piles $\mathrm{A}^{\prime}$ and $\mathrm{A}$ had moisture values higher than the maximum recommended by the NTC 5167 norm (Icontec, 2003).

The adding of BM (SCB and SG) favored a major TOC content in both products making them to agree with the minimal value reported by the NTC 5167 norm (Icontec, 2003). This property helps to improve the quality of the product, a critical variable for the composting facilities in the zone of study. Additional to high TOC value, other parameters like high CEC, reduction of $\mathrm{BD}$ and increasing of WHC (Table 2 ), could to improve soils quality after application of these products. Indeed, for a major water and nutrient retention, physical properties improving and soils bacterial activity increasing could be observed (Aggelides and Londra, 2000).

Concerning to $\mathrm{N}_{\text {Total }}$, although the main objective of BM is to supply structural support to mixture, the adding of $\mathrm{SG}$ also supplied $\mathrm{N}\left(\mathrm{N}_{\text {Total }}\right.$ value $=1.53 \% \pm$ $0.04 \%$ ), allowing products $\mathrm{B}$ to agree with the minimal value reported by the NTC 5167 norm (Icontec, 2003). In contrast, when SCB was added a lower $\mathrm{N}_{\text {Total }}$ value was observed for products A $(0.90 \% \pm 0.69 \%)$, if it is compared with the value for its starting control A' $(1.54 \%$ $\pm 0.51 \%)$; this fact could be associated with decreasing caused by the initial low $\mathrm{N}_{\text {Total }}$ content $(0.47 \% \pm 0.00 \%)$ found in $\mathrm{BM}$ (SCB).

The $\mathrm{C} / \mathrm{N}$ ratio of a product should be in the range of 10-15 (Sullivan and Miller, 2001). This situation was observed for products of piles (control B') (14.77). In the case of products of piles B the low value (9.67) is associated with the high $\mathrm{N}_{\text {Total }}$ content in $\mathrm{SG}$, while for products of piles $\mathrm{A}$ the high $\mathrm{C} / \mathrm{N}$ ratio is associated with low $\mathrm{N}_{\text {Total }}$ content and high TOC supplied by the SCB. Aggelides and Londra (2000) argue that use of high $\mathrm{C} / \mathrm{N}$ ratio materials (like products $\mathrm{A}$ ) are benefits for recovering and formation of soils, constituting them into an alternative of cover materials for erosion control, due to the their high lignin content, a precursor for humus formation in soils (Amalfitano et al., 2006).

It has been observed that products derivated from composting processes have $\mathrm{P}$ and $\mathrm{K}$ typical values in ranges of $0.4 \%-1.1 \%$ and $0.6 \%-1.7 \%$, respectively (Herity, 2003). It is remarkable that in our study, both controls as well as products showed higher $\mathrm{P}$ and $\mathrm{K}$ values than the required which is in agreement with the NTC 5167 norm (Icontec, 2003).

Table 2. Quality of the obtained products in piles of the experiments 1 and 2.

\begin{tabular}{|c|c|c|c|c|c|c|c|}
\hline \multirow[b]{2}{*}{ Parameters } & \multicolumn{3}{|c|}{ Experiment 1} & \multicolumn{3}{|c|}{ Experiment 2} & \multirow[b]{2}{*}{ NTC 5167} \\
\hline & Pile A' & Pile A & p-value & Pile B' & Pile B & p-value & \\
\hline $\mathrm{pH}$ & $8.01 \pm 0.13$ & $7.38 \pm 0.07$ & 0 & $10.10 \pm 0.28$ & $9.90 \pm 0.17$ & 0.318 & $>4$ and $<9$ \\
\hline Moisture, \% & $39.00 \pm 0.87$ & $49.47 \pm 11.14$ & 0 & $32.77 \pm 5.62$ & $34.50 \pm 3.29$ & 0.714 & $<35$ \\
\hline TOC, $\%$ & $12.77 \pm 1.97$ & $17.77 \pm 1.46$ & 0 & $13.73 \pm 0.40$ & $18.87 \pm 2.70$ & 0 & $>15$ \\
\hline NTotal, \% & $1.54 \pm 0.51$ & $0.90 \pm 0.69$ & 0.092 & $0.90 \pm 0.12$ & $2.02 \pm 0.50$ & 0 & $>1$ \\
\hline $\mathrm{C} / \mathrm{N}$ & $9.43 \pm 5.37$ & $28.23 \pm 18.79$ & 0.122 & $14.77 \pm 1.89$ & $9.67 \pm 3.13$ & 0.098 & - \\
\hline Ashes, \% & $62.63 \pm 1.93$ & $57.23 \pm 1.00$ & 0 & $65.67 \pm 2.28$ & $61.03 \pm 1.33$ & 0 & $<60$ \\
\hline KTotal, \% & $3.78 \pm 0.37$ & $3.11 \pm 0.40$ & 0 & $3.23 \pm 0.38$ & $3.92 \pm 0.13$ & 0.293 & $>1$ \\
\hline PTotal, \% & $1.45 \pm 0.17$ & $1.04 \pm 0.08$ & 0 & $1.32 \pm 0.06$ & $1.26 \pm 0.10$ & 0 & $>1$ \\
\hline $\mathrm{BD}, \mathrm{g} \mathrm{cm}^{-3}$ & $0.61 \pm 0.03$ & $0.44 \pm 0.07$ & 0 & $0.55 \pm 0.07$ & $0.34 \pm 0.04$ & 0 & $<0.6$ \\
\hline WHC, \% & $124.4 \pm 7.1$ & $168.83 \pm 9.91$ & 0 & $120.4 \pm 6.9$ & $165.6 \pm 18.6$ & 0 & $>100$ \\
\hline $\mathrm{EC}, \mathrm{dS} \mathrm{m}^{-1}$ & $0.74 \pm 0.23$ & $0.43 \pm 0.07$ & 0 & $0.49 \pm 0.07$ & $0.49 \pm 0.07$ & 0.907 & - \\
\hline CEC, meq $100 \mathrm{~g}^{-1}$ & $52.3 \pm 0.9$ & $56.2 \pm 1.87$ & 0 & $49.7 \pm 1.56$ & $50.0 \pm 2.7$ & 0.694 & $>30$ \\
\hline TFC, NMP g-1 & 809.3 & 751.0 & 0.888 & 10.0 & 7.7 & 0.703 & - \\
\hline TC, NMP g ${ }^{-1}$ & 17.0 & 23.0 & 0.814 & 0.0 & 0.0 & 0.903 & - \\
\hline
\end{tabular}

Average data \pm standard deviation.

TOC: total organic C; $\mathrm{N}_{\text {Total }}$ : total N; $\mathrm{K}_{\text {Total }}$ : total K, $\mathrm{P}_{\text {Total }}$ : total P; BD: bulk density; WHC: water holding capacity; EC: electric conductivity; CEC: cation-exchange capacity; TFC: total fecal coliforms; TC: total coliforms; NTC 5167: Colombian Technical Norm (Icontec, 2003).

Experiment 1: $78 \%$ Biowastes (BW) and 22\% sugarcane bagasse; Experiment 2: $66 \%$ BW and $34 \%$ star grass. 
On the other hand, all piles showed low EC values in agreement with the ranges recommended by Getahun et al. (2012) $\left(<3 \mathrm{dS} \mathrm{m}^{-1}\right)$ for use in agriculture, permitting to suppose that salts content in form of chlorides and sulfates of $\mathrm{Na}$ or $\mathrm{K}$ would not affect plants growing if these products (A, $\left.\mathrm{A}^{\prime}, \mathrm{B}^{\prime}, \mathrm{B}\right)$ are applied in soils.

Regarding to TC and TFC, it was observed that product of experiments 1 and 2 did not show significant differences between them. Despite that the NTC 5167 norm (Icontec, 2003) does not limit the TFC, the results shows a low content of them in controls $\left(\mathrm{A}^{\prime}\right.$ and $\mathrm{B}^{\prime} ; 17$ and 0 , respectively) and products (A and $\mathrm{B} ; 23$ and 0 , respectively) (Table 2), in agreement with the minimal indicated (lower than 1000) by norms like US-EPA (1994). Low content of TFC in both experiments 1 and 2, mainly in products of piles $\mathrm{B}^{\prime}$ and $\mathrm{B}$ indicate the effectiveness of hygienization processes of materials. This fact is associated with keeping thermophilic conditions during periods over than $15 \mathrm{~d}$ in all experimental unities.

Figure 6 describe GI values of the experimental units for experiment 1 (piles $\mathrm{A}^{\prime}$ and $\mathrm{A}$ ) and experiment 2 (piles $\mathrm{B}^{\prime}$ and $\mathrm{B}$ ). It was observed that piles A had high GI values $(55 \%-87 \%)$ at the end of the experiments while piles B did not reach at least 50\%, although they were higher than those for control piles B'. The high GI values for piles A could be associated to their low EC and almost neutral $\mathrm{pH}$ values found for these piles (Table 2), evidencing a minor
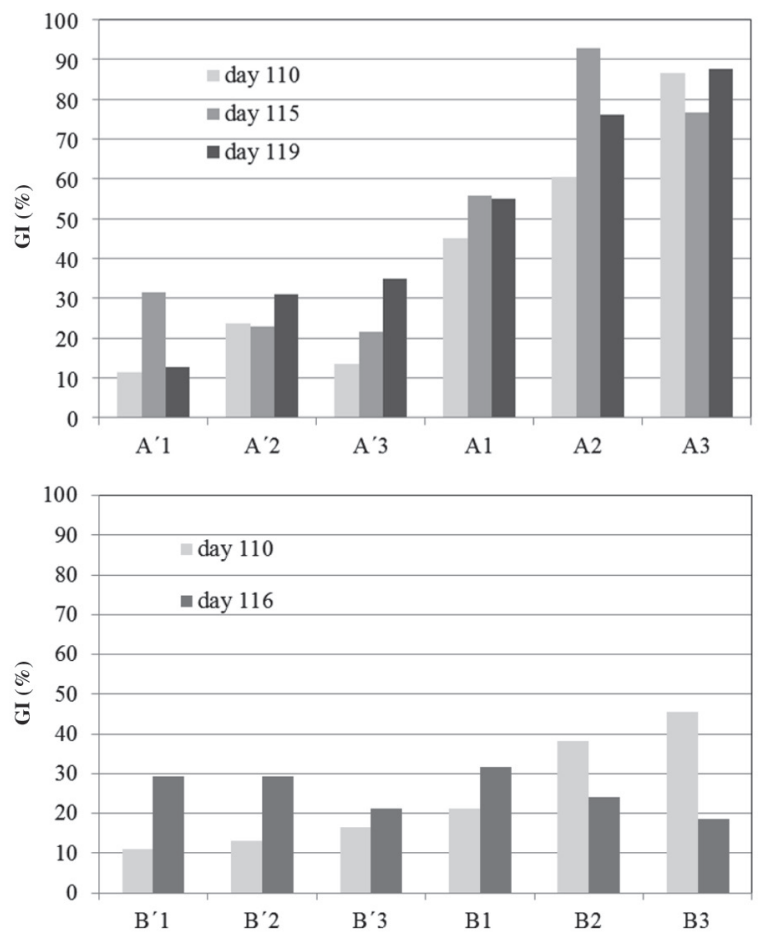

Experiment 1: 78\% Biowastes (BW) and 22\% sugarcane bagasse; Experiment 2: $66 \% \mathrm{BW}$ and $34 \%$ star grass.

Figure 6. Germination index (GI) evolution in piles of the experiments 1 and 2. presence of salts, and for instance, a minimal phytotoxic effect over plants growing (Ali et al., 2013).

Finally, it is worth mention that in the remaining experimental unities (products of piles $\mathrm{A}^{\prime}, \mathrm{B}^{\prime}$, and $\mathrm{B}$ ), it was reached high germination percentages (relative germination percentages [RGP] in range of 70\%-100\%) in all cases, although low roots growing (root growing percentages [rGP] in range of $17 \%-40 \%$ ), which could be associated with a possible immature stage of such products (Varnero et al., 2007).

\section{CONCLUSIONS}

The effect of adding sugarcane bagasse and star grass as bulking materials over the process and obtained products quality from the composting process of municipal biowastes was evaluated. Bulking materials were effective for speeding up the degradation of the organic materials in starting step of composting process, reducing required time to achieve temperatures for thermophilic phase and lowering the lasting of mesophilic and thermophilic phases. Nevertheless, the presence of hard-to-degrade compounds, like lignin, in both BMs increased cooling and maturation phases duration. Additionally, the presence of these bulking materials improved obtained products quality, in terms of better total organic C, ashes, bulk density, water holding capability, and cation-exchange capacity parameters, permitting anticipate that applying of these products in soils could improve some of their critical properties like macronutrients, water retention, and microbial activity.

\section{ACKNOWLEDGEMENTS}

Authors thank to Universidad del Valle for the financial support and Cooperativa de Servicios Públicos de Versalles, Camino Verde APC for experimental support. Ricardo Oviedo-Ocaña thanks COLCIENCIAS for his doctoral fellowship and Universidad Industrial de Santander (UIS) for the support received while writing this paper.

\section{LITERATURE CITED}

Adhikari, B., S. Barrington, J. Martinez, and S. King. 2008. Characterization of food waste and bulking agents for composting. Waste Management 28:795-804.

Aggelides, M., and P. Londra. 2000. Effects of compost produced from town wastes and sewage sludge on the physical properties of a loamy and a clay soil. Bioresource Technology 71:253-259.

Agnew, J.M., and J.J. Leonard. 2003. The physical properties of compost. Compost Science \& Utilization 11:238-264.

Ali, U., A. Khalid, T. Mahmood, and I. Aziz. 2013. Accelerated biodegradation of solid organic waste through biostimulation. Proceedings of the Pakistan Academy of Sciences 50:37-46.

Amalfitano, C., V. Pignalosa, L. Auriemma, and A. Ramunni. 2006. The contribution of lignin to the composition of humic acids from a wheat-straw amended soil during 3 years of incubation in pots. European Journal of Soil Science 43:495-504. 
Balakrishnan, M., and V.S. Batra. 2011. Valorization of solid waste in sugar factories with possible applications in India: A review. Journal of Environmental Management 92:2886-2891.

Chiumenti, A., R. Chiumenti, L.F. Diaz, G. Savage, L. Eggerth, and N. Goldstein. 2005. Modern composting technologies. J.G. Press, Emmaus, Pennsylvania, USA.

De Guardia, A., P. Mallard, C. Teglia, A. Marin, C. Le Pape, M. Launay, et al. 2010. Comparison of five organic wastes regarding their behaviour during composting: Part 1. Biodegradability, stabilization kinetics and temperature rise. Waste Management 30:402-414.

Dormond, H., C. Boschini, A. Rojas-Bourrillón, y A. Zúñiga. 1998. Efecto de cuatro niveles de cáscara de banano maduro sobre la degradabilidad ruminal de la materia seca de los pastos Kikuyo (Pennisetum clandestinum) estrella africana (Cynodon nlemfluensis) en vacas Jersey. Agronomía Costarricense (Costa Rica) 22:163-172.

Epstein, E. 2011. Industrial composting: environmental engineering and facilities management. CRC Tailor \& Francis Group, Boca Raton, Florida, USA.

Forster-Carneiro, T., M. Pérez, and L.I. Romero. 2008. Thermophilic anaerobic digestion of source-sorted organic fraction of municipal solid waste. Bioresource Technology 99:6763-6770.

Francou, C., M. Linères, S. Derenne, M. Le Villio-Poitrenaud, and S. Houot. 2008. Influence of green waste, biowaste and papercardboard initial ratios on organic matter transformations during composting. Bioresource Technology 99:8926-8934.

Gajalakshmi, S., and S.A. Abbasi. 2008. Solid waste management by composting: State of the art. Critical Reviews in Environmental Science and Technology 38:311-400.

Getahun, T., A. Nigusie, T. Entele, T.V. Gerven, and B. Van der Bruggen. 2012. Effect of turning frequencies on composting biodegradable municipal solid waste quality. Resources, Conservation and Recycling 65:79-84.

Gustavsson, J., C. Cederberg, U. Sonesson, R. Van Otterdijk, and A. Meybeck. 2011. Global food losses and food waste. Food and Agriculture Organization of the United Nations (FAO), Rome, Italy.

Haug, R.T. 1993. The practical handbook of compost engineering. Lewis Publishers, Boca Raton, Florida, USA.

Herity, L. 2003. A study of the quality of waste derived compost in Ireland. Thesis Master of Science in Environmental Engineering. Queens University of Belfast, Belfast, Ireland.

Icontec. 1997. Norma Técnica Colombiana NTC 370. Abonos o fertilizantes. Determinación de nitrógeno total. p. 1-7. Instituto Colombiano de Normas Técnicas y Certificación (Icontec), Bogotá, Colombia.

Icontec. 2001. Norma Técnica Colombiana NTC 234. Abonos o fertilizantes. Método de ensayo para la determinación cuantitativa de fósforo. p. 1-18. Instituto Colombiano de Normas Técnicas y Certificación (Icontec), Bogotá, Colombia.

Icontec. 2003. Norma Técnica Colombiana NTC 5167. Productos para la industria agrícola. Productos orgánicos usados como abonos o fertilizantes y enmiendas de suelo. p. 1-43. Instituto Colombiano de Normas Técnicas y Certificación (Icontec), Bogotá, Colombia.

Iqbal, M.K., T. Shafiq, and K. Ahmed. 2010. Characterization of bulking agents and its effects on physical properties of compost. Bioresource Technology 101:1913-1919.

Kalemelawa, F., E. Nishihara, T. Endo, Z. Ahmand, R. Yeasmin, M.M. Tenywa, et al. 2012. An evaluation of aerobic and anaerobic composting of banana peels treated with different inoculums for soil nutrient replenishment. Bioresource Technology 126:375-382.

Krogmann, U., I., Körner, and L.F. Diaz. 2010. Composting: Technology. p. 533-568. In T. Christensen (ed.) Solid waste technology \& management. John Wiley \& Sons, New Delhi, India.

Kumar, M., Y.L. Ou, and J.G. Lin. 2010. Co-composting of green waste and food waste at low $\mathrm{C} / \mathrm{N}$ ratio. Waste Management 30:602-609.
Li, Z., H. Lu, L. Ren, and L. He. 2013. Experimental and modeling approaches for food waste composting: A review. Chemosphere 93:1247-1257.

López, M., M. Soliva, F.X. Martínez-Farré, A. Bonmatí, and O. Huerta-Pujol. 2010. An assessment of the characteristics of yard trimmings and recirculated yard trimmings used in biowaste composting. Bioresource Technology 101:1399-1405.

Meunchang, S., S. Panichsakpatana, and R.W. Weaver. 2005. Cocomposting of filter cake and bagasse; by-products from a sugar mill. Bioresource Technology 96:437-442.

Monson, C., and A. Murugappan. 2010. Developing optimal combination of bulking agents in an In-Vessel composting of vegetable waste. Journal of Chemistry 7:93-100.

Oviedo-Ocaña, R., M. Daza-Torres, L. Marmolejo-Rebellón, A. Osorio-Ortiz, y P. Torres-Lozada. 2013. Influencia de la incorporación de pasto estrella como material de soporte (Cynodon plectostachyus) en el compostaje de biorresiduos de origen municipal. Ingeniería y Desarrollo 31:251-271.

Pigozzo, A.T.G., E. Lenzi, J.L. Junior, C. Scapin, and A.C.S. Da Costa. 2006. Transition metal rates in latosol twice treated with sewage sludge. Brazilian Archives of Biology and Technology 49:515-526

R Development Core Team. 2008. R: A language and environment for statistical computing. R Foundation for Statistical Computing, Vienna, Austria.

Satisha, G.C., and L. Devarajan. 2007. Effect of amendments on windrow composting of sugar industry pressmud. Waste Management 27:1083-1091.

Sakurai, K. 2001. Método sencillo del análisis de residuos sólidos. Hojas de Divulgación Técnica (HDT) 17. Centro Panamericano de Ingeniería Sanitaria y Ciencias del Ambiente (CEPIS). Available at http://www.bvsde.paho.org/cdromrepi86/fulltexts/eswww/proyecto/repidisc/publica/hdt/hdt017. html (accessed October 2013).

Smårs, S., L. Gustafsson, B. Beck-Friis, and H. Jönsson. 2002. Improvement of the composting time for household waste during an initial low $\mathrm{pH}$ phase by mesophilic temperature control. Bioresource Technology 84:237-241.

Sullivan, D.M., and R.O. Miller. 2001. Compost quality attributes, measurements, and variability. p. 95-120. In Stoffella, P.J., and B.A. Kahn (eds.) Compost utilization in horticultural cropping systems. Lewis Publishers, Boca Raton, Florida, USA.

Sundberg, C., I.H. Franke-Whittle, S. Kauppi, D. Yu, M. Romantschuk, H. Insam, et al. 2011. Characterisation of sourceseparated household waste intended for composting. Bioresource Technology 102:2859-2867.

Sundberg, C., and H. Jönsson. 2005. Process inhibition due to organic acids in fed-batch composting of foodwaste - influence of starting culture. Biodegradation 16:205-213.

Sundberg, C., S. Smårs, and H. Jönsson. 2004. Low pH as an inhibiting factor in the transition from mesophilic to thermophilic phase in composting. Bioresource Technology 95:145-150

Tosun, I., M.T. Gönüllü, E., Arslankaya, and A. Günay. 2008. Cocomposting kinetics of rose processing waste with OFMSW. Bioresource Technology 99:6143-6149.

US-EPA. 1994. Standards for the use or disposal of sewage sludge. 58 FR 9248. Federal Register, Environmental Protection Agency (EPA), US Government Printing Office, Washington, USA.

Varnero, M.T., A.C. Rojas, y R.R. Orellana. 2007. Índices de fitotoxicidad en residuos orgánicos durante el compostaje. Revista de la Ciencia del Suelo y Nutrición Vegetal 7:28-37.

Yang, F., G.X. Li, Q.Y. Yang, and W.H. Luo. 2013. Effect of bulking agents on maturity and gaseous emissions during kitchen waste composting. Chemosphere 93:1393-1399.

Zhu, N. 2007. Effect of low initial $\mathrm{C} / \mathrm{N}$ ratio on aerobic composting of swine manure with rice straw. Bioresource Technology 98:9-13. 